\title{
Review \\ Combination of Entecavir or Tenofovir with Pegylated Interferon- $\alpha$ for Long-Term Reduction in Hepatitis B Surface Antigen Levels: Simultaneous, Sequential, or Add-on Combination Therapy
}

\author{
Kanako Yoshida $^{1}$, Masaru Enomoto ${ }^{1, *}$, Akihiro Tamori ${ }^{1} \mathbb{D}$, Shuhei Nishiguchi ${ }^{2,3}$ and Norifumi Kawada ${ }^{1}$ \\ 1 Department of Hepatology, Graduate School of Medicine, Osaka City University, Osaka 545-8585, Japan; \\ mykanako@gmail.com (K.Y.); atamori@med.osaka-cu.ac.jp (A.T.); kawadanori@med.osaka-cu.ac.jp (N.K.) \\ 2 Division of Medical Science of Regional Cooperation for Liver Diseases, Graduate School of Medicine, \\ Osaka City University, Osaka 545-8585, Japan; nishiguchi@heartfull.or.jp \\ 3 Department of Internal Medicine, Kano General Hospital, Osaka 531-0041, Japan \\ * Correspondence: enomoto-m@med.osaka-cu.ac.jp; Tel.: +81-666-453-811
}

check for updates

Citation: Yoshida, K.; Enomoto, M.; Tamori, A.; Nishiguchi, S.; Kawada, N. Combination of Entecavir or Tenofovir with Pegylated Interferon- $\alpha$ for Long-Term Reduction in Hepatitis B Surface Antigen Levels: Simultaneous, Sequential, or Add-on Combination Therapy. Int. J. Mol. Sci. 2021, 22, 1456. https://doi.org/10.3390/ ijms22031456

Received: 10 December 2020

Accepted: 27 January 2021

Published: 1 February 2021

Publisher's Note: MDPI stays neutral with regard to jurisdictional claims in published maps and institutional affiliations.

Copyright: (c) 2021 by the authors. Licensee MDPI, Basel, Switzerland. This article is an open access article distributed under the terms and conditions of the Creative Commons Attribution (CC BY) license (https:// creativecommons.org/licenses/by/ $4.0 /)$.

\begin{abstract}
Seroclearance of hepatitis B surface antigen (HBsAg) ("functional cure") is the optimal endpoint of antiviral therapy for chronic hepatitis B virus (HBV) infection. Currently available anti-HBV therapy includes nucleoside/nucleotide analogs (NAs) and peginterferon- $\alpha$ (Peg-IFN $\alpha$ ). Combination of NAs and Peg-IFN $\alpha$, each with different mechanisms of action, is an attractive approach for treating chronic HBV infection. In earlier studies, compared with monotherapy using IFN $\alpha$, combination therapy showed greater on-treatment HBV DNA suppression but no difference in the sustained response. However, responses to the combination of non-pegylated IFN $\alpha$ with lamivudine or adefovir were not assessed based on HBsAg quantification but were defined by normal alanine aminotransferase levels, testing negative for hepatitis B e-antigen, and low HBV DNA load over a short term. Here, we reviewed previous reports regarding the effects of combination therapy of entecavir or tenofovir with Peg-IFN $\alpha$, focusing on long-term reduction in HBsAg levels. Regimens of combination therapy were classified into "simultaneous" combination ("de novo" strategy); "sequential" combination, which involved starting with one therapy followed by the other ("switch-to" strategy); "add-on" combination, which involved adding Peg-IFN $\alpha$ to an ongoing NAs. Some studies have shown promising results, but there is no robust evidence that combination therapy is superior to monotherapy. Large studies are needed to assess the safety and efficacy of combination therapies to increase the rates of HBsAg seroclearance over the long term.
\end{abstract}

Keywords: chronic hepatitis B; ETV; HBsAg; HBV; peginterferon- $\alpha$; TDF

\section{Introduction}

Hepatitis B virus (HBV) infection affects approximately 240 million people worldwide and is the major cause of cirrhosis and hepatocellular carcinoma (HCC), accounting for 686,000 deaths annually [1]. Seroclearance of hepatitis B surface antigen (HBsAg) (i.e., "functional cure") is regarded as the optimal endpoint of anti-HBV therapy to reduce HBVrelated mortality because HBsAg loss is associated with improved survival and quality of life by preventing disease progression [1-4]. To reach the endpoint, several novel agents, direct-acting antivirals, and host-targeting antivirals are under clinical investigation [5]; however, unfortunately, they are not expected to be approved until a few years.

Currently available anti-HBV therapeutic drugs can be divided into two classes: nucleoside/nucleotide analogs (NAs) and immunomodulator pegylated interferon- $\alpha$ (PegIFN $\alpha$ ). NAs efficiently suppress the pathway of HBV replication by inhibiting reverse transcription and terminating DNA chain elongation [6]. The action of NAs has little effect on the decrease in the intrahepatic replicative intermediate, a covalently closed 
circular DNA (cccDNA). However, increased endogenous IFN- $\lambda 3$ due to treatment with a nucleotide analog may induce the expression of IFN-stimulated genes, thereby, resulting in reduced production of HBsAg [7-10]. In addition, in vitro and ex vivo studies have shown that long-term treatment with NAs could restore T-cell functions [11,12]. The major advantages of NAs include excellent safety profiles and potent antiviral activity associated with high rates of on-treatment response. Peg-IFN $\alpha$ has been shown to have both direct antiviral and immunomodulatory effects [6]. Treatment with IFN $\alpha$ can inhibit HBV replication by accelerating the degradation of pregenomic HBV RNA and decay of the core particle [13]. Moreover, it decreases the transcription of subgenomic RNA [14], which leads to a significant expansion of CD56 ${ }^{\text {bright }} \mathrm{NK}$ cells, accompanied by augmentation of TNF-related apoptosis-inducing ligand and IFN- $\gamma$ expression [15]. The advantages of IFN $\alpha$ include finite course of treatment, absence of drug resistance, and durability of response post-treatment.

Theoretically, combination therapy with NAs and Peg-IFN $\alpha$, each with different mechanisms of action, is an attractive approach for treating chronic HBV infection. Fundamentally, the suppression of viral replication by NAs may restore the innate and adaptive immune responses and optimize the immunomodulatory effects of IFN $\alpha$ for clearing infected cells. This may be due to the degradation of $\operatorname{cccDNA}$ by IFN $\alpha$, followed by decline in the secretion of HBsAg antigen, and restoration of HBV-specific T cells, which causes further decline in intranuclear cccDNA levels. In 2013, we had reviewed previous reports of "simultaneous" [16,17] and "sequential" [18,19] combination therapies with NA and IFN $\alpha$ for chronic HBV infection [20]. When the combination therapy (NA and IFN $\alpha$ ) was compared with monotherapy (IFN $\alpha$ ), the former showed greater on-treatment viral suppression, but no difference was observed in the sustained response post-treatment. However, in almost all of these studies, responses to therapy were not assessed based on HBsAg quantification but were defined by normal alanine aminotransferase (ALT) levels, testing negative for hepatitis B e-antigen (HBeAg), and low HBV DNA load over a short term (e.g., at 24 or 48 weeks post-treatment). First generation NA (lamivudine or adefovir) in combination with non-pegylated IFN $\alpha$ was used in most of these studies. Since then, new generation nucleoside analogs, such as entecavir (ETV) [21,22]; nucleotide analogs, such as tenofovir disoproxil fumarate (TDF) [23] or tenofovir alafenamide (TAF) [24,25]; and Peg-IFN $\alpha[16,17]$ have become the first-line treatment. In addition, reports on "add-on" combination therapy have also been accumulated.

In this review, we summarized reports regarding the effects of combination therapy of potent NAs (ETV, TDF, or TAF) with Peg-IFN $\alpha$, especially focusing on the long-term reduction of HBsAg levels. Regimens of combination therapy were classified based on the methods of drug administration: simultaneous ("de novo" strategy); sequential, in which one therapy is followed by another ("switch-to" strategy); add-on, in which Peg-IFN $\alpha$ is added to an ongoing NAs (Figure 1).

A) Simultaneous combination
('de novo' strategy)

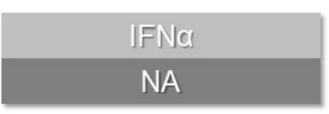

B) Sequential combination ('switch-to' strategy)

NA IFNa

C) Add-on combination

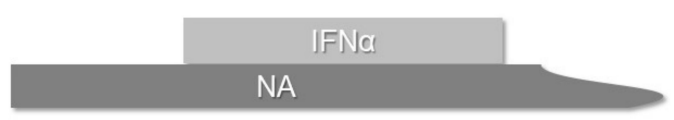

Figure 1. Regimens of combination therapy were classified based on the methods of drug administration: (A) simultaneous combination ("de novo") strategy, (B) sequential combination ("switch-to") strategy, and (C) add-on combination therapy. 


\section{Simultaneous ("De Novo") Combination Strategy}

Table 1 shows a summary of previous studies concerning simultaneous combination therapy for chronic HBV infection with new NAs and Peg-IFN $\alpha$. These studies were grouped into ETV-based and TDF-based studies. A randomized controlled trial conducted in Thailand by enrolling HBeAg-negative patients with predominantly the genotype $C$ showed that compared with monotherapy with 48 -week Peg-IFN $\alpha$, simultaneous combination therapy with 48-week ETV + Peg-IFN $\alpha$ did not improve the decline in HBsAg levels and HBsAg loss rate after 1 year of treatment $\left(0.7\right.$ vs. $0.5 \log _{10} \mathrm{IU} / \mathrm{mL}, p=0.12 ; 9.5 \%$ vs. $4.8 \%, p=0.49$ ) [26]. However, Hagiwara et al. conducted a long-term, single-arm study with a mean follow-up period of 4.8 years, showing that HBeAg-positive and -negative patients with predominance of genotype $\mathrm{C}$, who were treated with 48-week ETV and Peg-IFN $\alpha$, had HBsAg loss rate of $3.8 \%$ after 1 year, $8.4 \%$ after 3 years, and $15 \%$ after 5 years post-treatment $[27,28]$. In addition, this observational study monitored changes in cccDNA levels in liver biopsies and found that the average reduction in cccDNA level was $1.4 \log _{10}$ copies/ $\mu g$ after the completion of therapy. 
Table 1. Simultaneous (de novo) combination therapy with NA and Peg-IFN $\alpha$.

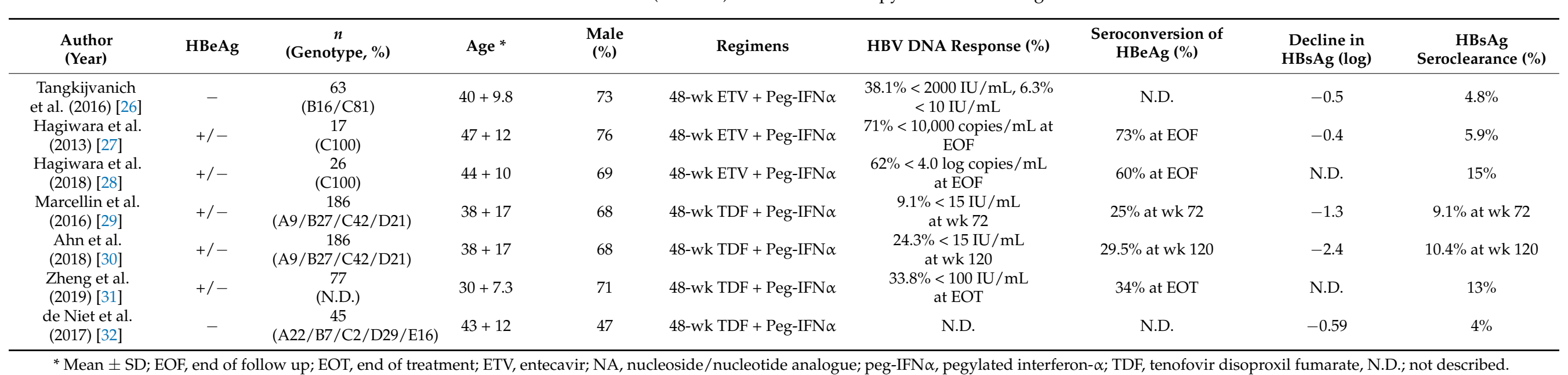

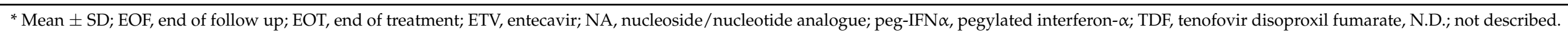


Marcellin et al. [29] conducted an international, randomized trial in HBeAg-positive and -negative patients and demonstrated that compared with monotherapy, the simultaneous combination therapy of 48-week TDF + Peg-IFN $\alpha$ improved the decline in HBsAg levels and HBsAg loss after 0.5 years of treatment $\left(1.3,0.6\right.$, and $0.4 \log _{10} \mathrm{IU} / \mathrm{mL}, p<0.05$; $9.1 \%, 2.8 \%$, and $0 \%, p<0.05$ in combination, Peg-IFN $\alpha$ monotherapy, and TDF monotherapy, respectively). Notably, the combination therapy resulted in a particularly high rate of HBsAg loss of $35 \%$ in patients with genotype A HBV infection. The long-term follow-up of this study confirmed the results from earlier time points; the combination therapy reduced HBsAg levels by $2.4 \log _{10} \mathrm{IU} / \mathrm{mL}$ and the rate of HBsAg loss by $10.4 \%$ after 1.5 years of the treatment [30]. Additionally, in a nonrandomized controlled trial in China, HBsAg loss was observed in $13 \%$ of $\mathrm{HBeAg}$-positive and -negative patients in the TDF and Peg-IFN $\alpha$ groups after 48 weeks, whereas this was observed in only 3\% patients in the Peg-IFN $\alpha$ group ( $p=0.032)$ [31]. Here, low baseline levels of HBsAg levels after 48 weeks of treatment (odds ratio $=0.22, p=0.005$ ) was an independent factor associated with HBsAg seroclearance.

Another group from the Netherlands conducted a randomized trial on $\mathrm{HBeAg}-$ negative patients with HBV DNA load < 20,000 IU/mL [32], although such patients with a low HBV DNA load and no signs of necroinflammatory activity or fibrosis currently have no indicators for treatment. This study showed that simultaneous combination therapy with 48-week TDF + Peg-IFN $\alpha$ led to further decease in HBsAg levels ( 0.59 vs. $0.15 \log _{10} \mathrm{IU} / \mathrm{mL}, p=0.001$ ) and did not improve the rate of HBsAg loss compared with the no-treatment group, after 0.5 years of therapy ( $4 \%$ vs. $0 \%, p=0.38$ ).

To summarize, it remains unclear whether simultaneous combination therapy of ETV or TDF with Peg-IFN $\alpha$ confers any additional benefits compared with monotherapy. The conflicting results of the two randomized trials may be attributable to the use of different NAs (ETV vs. TDF), but more likely owing to different genotype distribution: one study enrolled an Asian population with predominantly genotype $C$ [26] and the other was an international study with all major genotypes [29]. Further studies are needed to determine the impact of simultaneous combination of ETV or TDF with Peg-IFN $\alpha$ for treating chronic HBV infection.

\section{Sequential ("Switch-to") Combination Strategy}

Table 2 shows a summary of previous studies assessing sequential combination therapy for chronic HBV infection, with new NAs followed by switching to Peg-IFN $\alpha$. A randomized controlled OSST trial in China [33] enrolled HBeAg-positive patients with consistent HBV DNA load $\leq 1000$ copies/mL and HBeAg levels $<100 \mathrm{PEIU} / \mathrm{mL}$ after ETV treatment for 9-36 months. Following sequential combination therapy by switching to 48 -week Peg-IFN $\alpha$, a greater proportion of patients had HBsAg levels $<10 \mathrm{IU} / \mathrm{mL}$ and higher rates of HBsAg loss compared with those following continued treatment with ETV, at the end of treatment $(15.9 \%$ vs. $0 \%, p<0.0001 ; 8.5 \%$ vs. $0 \%, p=0.003)$. One-year follow-up of the study indicated that sustained HBsAg loss was documented in six of seven patients with an end-of-treatment response [34]. Similarly, another randomized trial in China [35] enrolled HBeAg-positive patients who achieved HBeAg seroconversion for $>1$ year with NAs (primarily ETV); the authors indicated that the discontinuation of treatment while switching to 48 -week consolidation therapy with Peg-IFN $\alpha$ was associated with a lower risk of relapse and higher chance of HBsAg loss than consolidation therapy with NAs, during 96 weeks of post-treatment follow-up ( $25 \%$ vs. $58 \%, p=0.020 ; 36 \%$ vs. $4.3 \%, p=0.013$ ).

Two controlled randomized trials in China explored the optimal duration for PegIFN $\alpha$ in sequential combination therapy. Of these, one trial enrolling $\mathrm{HBeAg}$-positive and -negative patients with consistent HBV DNA load $<20 \mathrm{IU} / \mathrm{mL}$ and HBsAg levels $<2000 \mathrm{IU} / \mathrm{mL}$ after long-term treatment with an NA showed that only patients who switched to 60-week Peg-IFN $\alpha$ achieved HBsAg loss (32.6\%) and HBsAg seroconversion $(25.6 \%)$, after 1 year of treatment. However, the rates of responses did not increase following extended treatment with Peg-IFN $\alpha$ [36]. Another randomized New Switch trial enrolled 
HBeAg-positive patients who achieved HBeAg loss and HBV DNA load $<200 \mathrm{IU} / \mathrm{mL}$ following NA treatment for 1-3 years. It reported that sequential therapy with 96-week Peg-IFN $\alpha$ did not produce statistically higher rates of HBsAg loss compared with 48-week Peg-IFN $\alpha, 1$ year post-treatment (15.3\% vs. 9.8\%, $p=0.17)$ [37].

In the aforementioned studies, an objective of sequential combination therapy and switching to Peg-IFN $\alpha$ was to prevent the relapse of hepatitis following the discontinuation of long-term NA therapy. Another objective of this strategy can be to reduce the viral load using an NA, thereby restoring sensitivity to Peg-IFN $\alpha$. Notably, a randomized trial in China enrolled HBeAg-positive patients with a mean HBsAg level of $4.0 \log _{10} \mathrm{IU} / \mathrm{mL}$. This trial, however, failed to show that sequential combination therapy with ETV pretreatment for a short period ( 21 weeks) followed by Peg-IFN $\alpha$ treatment (48 weeks) improved the decline in HBsAg levels and rate of HBsAg loss compared with Peg-IFN $\alpha$ monotherapy (48 weeks), after 0.5 years of treatment ( 0.4 vs. $1.0 \log _{10} \mathrm{IU} / \mathrm{mL}, p=0.1 ; 1.4 \%$ vs. $4.2 \%$, $p=0.3)[38]$.

Outcomes of the sequential combination therapy involving switching from long-term NAs (mostly ETV) to 48-week Peg-IFN $\alpha$ have also been reported in Japan. Tamaki et al [39] conducted a nonrandomized controlled trial in HBeAg-positive and -negative patients treated with NAs for $>1$ year. They showed that the decline in HBsAg levels at week 48 after the switch in the sequential combination therapy group was significantly higher than that in the matched, continued NA-treatment group $\left(0.81 \pm 1.1 \mathrm{vs.} 0.11 \pm 0.3 \log _{10} \mathrm{IU} / \mathrm{mL}\right.$, $p<0.001)$. Regarding the factors associated with treatment response, Matsumoto et al. [40] conducted a nationwide prospective study and showed that low baseline levels of $\mathrm{HB}$ core-related antigen $[41,42]$ as well as low HBsAg levels $[33,37]$ were significant indicators of favorable outcomes after sequential therapy with NAs for $\geq 1$ year followed by switching to Peg-IFN $\alpha$. We also found that the early decline in HBsAg levels during treatment was associated with treatment response [43], as reported elsewhere [33,35,36]. 
Table 2. Sequential combination therapy involving switching from NA to Peg-IFN $\alpha$.

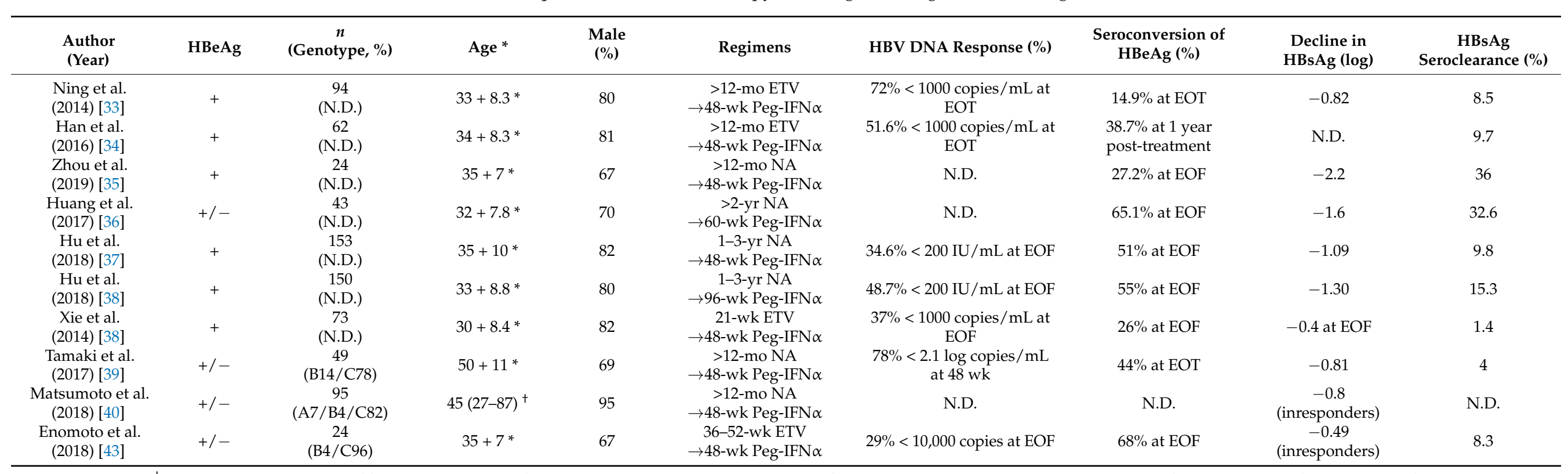

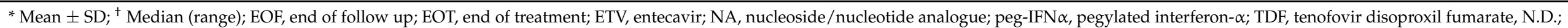
not described. 
Thus, sequential combination therapy, which involves switching from long-term NAs to Peg-IFN $\alpha$, is considered a safe method for terminating NA therapy [4]. Although it is still unclear which patients are good candidates for sequential combination therapy, low levels of $\mathrm{HBsAg}, \mathrm{HBeAg}$, or $\mathrm{HB}$ core-related antigen at the switch are indicators of good response. Rapid decline of $\mathrm{HBV}$ antigenemia after the start of treatment is also predictive of a favorable outcome. However, termination of NA therapy always has a risk of relapse or flare-up of hepatitis; sequential combination therapy should not be indicated for patients with cirrhosis without sufficient hepatic reserve.

\section{Add-on Combination Strategy}

Table 3 shows a summary of previous studies assessing the add-on combination therapy for chronic HBV infection, in which Peg-IFN $\alpha$ is added to an ongoing therapy with NAs. A randomized controlled ARES trial conducted in the Netherlands [44] enrolled HBeAg-positive patients and showed that the addition of short-term treatment with PegIFN $\alpha$ ( 24 weeks) to a 24-week ETV treatment further reduced HBsAg levels but maintained low HBsAg loss rate after 1 year of treatment, compared with ETV monotherapy $(0.8$ vs. $0.4 \log _{10} \mathrm{IU} / \mathrm{mL}, p<0.001 ; 1.2 \%$ vs. $0 \%, p=0.30$ ). The long-term follow-up results of this study reported that patients in the add-on group had $>1 \log _{10}$ decline in HBsAg levels than those in the monotherapy group after over 4 years post-treatment (59\% vs. $29 \%, p=0.02$ ); only one patient who received the add-on combination therapy reported HBsAg loss after 96 weeks [45]. Another randomized trial (PEGON) conducted in the Netherlands and China [46] enrolled HBeAg-positive patients with viral suppression by ETV or TDF for $>12$ months. This trial similarly showed that the addition of 48 -week PegIFN $\alpha$ led to further decline in HBsAg levels after 0.5 years post-treatment compared with NA monotherapy (0.4 vs. $\left.0.2 \log _{10} \mathrm{IU} / \mathrm{mL}, p=0.01\right)$. None of the patients showed HBsAg loss. In a post hoc analysis of two randomized trials [47] in which treatment response was defined by HBeAg loss and HBV DNA load $<200 \mathrm{IU} / \mathrm{mL}$ after 48 weeks of Peg-IFN $\alpha$, response was observed in 33\% and $20 \%$ patients receiving add-on combination therapy and monotherapy, respectively $(p=0.03)$. The highest response to add-on combination therapy was observed in patients with HBsAg levels $<4000 \mathrm{IU} / \mathrm{mL}$ and HBV DNA load $<50 \mathrm{IU} / \mathrm{mL}$ at randomization $(70 \%$ vs. $34 \% ; p=0.01)$. 
Table 3. Add-on combination therapy that involved adding Peg-IFN $\alpha$ to NA.

\begin{tabular}{|c|c|c|c|c|c|c|c|c|c|}
\hline $\begin{array}{l}\text { Author } \\
\text { (Year) }\end{array}$ & HBeAg & $\begin{array}{c}n \\
\text { (Genotype, \%) }\end{array}$ & Age * & $\begin{array}{c}\text { Male } \\
(\%)\end{array}$ & Regimens & $\begin{array}{c}\text { HBV DNA } \\
\text { Response (\%) }\end{array}$ & $\begin{array}{l}\text { Seroconversion of } \\
\text { HBeAg (\%) }\end{array}$ & $\begin{array}{l}\text { Decline in } \\
\text { HBsAg (log) }\end{array}$ & $\begin{array}{c}\text { HBsAg } \\
\text { Seroclearance (\%) }\end{array}$ \\
\hline $\begin{array}{l}\text { Brouwer et al. } \\
\text { (2015) [44] }\end{array}$ & + & $\begin{array}{c}85 \\
\text { (A5/B23/C39/D33) }\end{array}$ & $32+10 *$ & 74 & $\begin{array}{l}\text { 24-wk Peg-IFN } \alpha \\
\text { on 24-wk ETV }\end{array}$ & $\begin{array}{c}77 \%<200 \mathrm{IU} / \mathrm{mL}, 57 \%< \\
20 \mathrm{IU} / \mathrm{mL} \text { at EOF }\end{array}$ & $26 \%$ at $\mathrm{EOF}$ & -0.8 & 1.2 \\
\hline $\begin{array}{l}\text { Chi et al. } \\
\text { (2017) [46] }\end{array}$ & + & $\begin{array}{c}39 \\
(\mathrm{~B} 8 / \mathrm{C} 39 / \mathrm{D} 8)\end{array}$ & $35+9 *$ & 72 & $\begin{array}{c}\text { 48-wk Peg-IFN } \alpha \\
\text { on }>12 \text {-mo ETV } / \text { TDF }\end{array}$ & $77 \%<20 \mathrm{IU} / \mathrm{mL}$ at $\mathrm{EOF}$ & $21 \%$ at $\mathrm{EOF}$ & -0.35 & 0 \\
\hline $\begin{array}{l}\text { Liem et al. } \\
\text { (2019) [47] }\end{array}$ & + & $\begin{array}{c}118 \\
\text { (A3/B19/C38/D25) }\end{array}$ & $33+10 *$ & 74 & $\begin{array}{l}\text { 24-48-wk Peg-IFN } \alpha \\
\text { on }>24 \text {-wk ETV }\end{array}$ & $\begin{array}{c}85 \%<2000 \mathrm{IU} / \mathrm{mL}, 82 \%< \\
200 \mathrm{IU} / \mathrm{mL} \text { at EOF }\end{array}$ & $24 \%$ at $\mathrm{EOF}$ & $\begin{array}{c}23 \%>0.5 \log \\
\text { decline }\end{array}$ & 0.8 \\
\hline Li et al. (2015) [49] & + & $\begin{array}{c}81 \\
\text { (N.D.) }\end{array}$ & $32(23-54)^{+}$ & 62 & $\begin{array}{l}\text { 48-wk Peg-IFN } \alpha \\
\text { on ETV }\end{array}$ & N.D. & $48 \%$ & -0.96 & 4 \\
\hline $\begin{array}{l}\text { Matsumoto et al. } \\
\quad(2020)[50]\end{array}$ & $+1-$ & $\begin{array}{c}32 \\
(\mathrm{~A} 3 / \mathrm{B} 3 / \mathrm{C} 88 / \mathrm{D} 3)\end{array}$ & $43+8^{*}$ & 63 & $\begin{array}{l}\text { 48-wk Peg-IFN } \alpha \\
\text { on }>12 \text {-wk TDF }\end{array}$ & N.D. & $43 \%$ at EOT & -0.44 & 0 \\
\hline $\begin{array}{l}\text { Lampertico et al. } \\
\text { (2018) [51] }\end{array}$ & - & $\begin{array}{c}70 \\
(\mathrm{D} 100)\end{array}$ & $51(29-64)^{\dagger}$ & 81.4 & $\begin{array}{l}\text { 48-wk Peg-IFN } \alpha \\
\text { on NA }\end{array}$ & N.D. & N.D. & $\begin{array}{c}10.9 \% \geq 1 \log \\
\text { decline }\end{array}$ & 1.4 \\
\hline
\end{tabular}

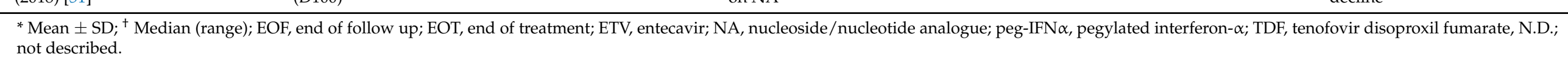


In addition, a randomized ANRS HB06 PEGAN trial in France among HBeAg-negative patients showed that the addition of 48-week Peg-IFN $\alpha$ to ongoing NA regimens for $\geq 1$ year led to further decline in HBsAg levels but to similar rate of HBsAg loss after 2 years of treatment compared with NA monotherapy (mostly ETV or TDF) (0.88 vs. $0.30 \log _{10}$ $\mathrm{IU} / \mathrm{mL}, p=0.004$ and $8 \%$ vs. $3 \%, p=0.15$ at week 96 with add-on combination therapy and monotherapy, respectively; 1.03 vs. $0.44 \log _{10} \mathrm{IU} / \mathrm{mL}, p<0.0001$ and $10 \%$ vs. $4 \%, p=0.11$ at week 144 with add-on combination therapy and monotherapy, respectively) [48].

Two nonrandomized controlled trials also yielded similar results. A multicenter study in China revealed that the addition of 48-week Peg-IFN $\alpha$ treatment for patients without HBeAg seroconversion during ETV therapy for $\geq 2$ years further declined HBsAg levels but maintained low rate of HBsAg loss compared with ETV monotherapy (0.96 vs. $0.02 \log _{10} \mathrm{IU} / \mathrm{mL}, p<0.001 ; 4 \%$ vs. $0 \%, p=0.49$ at week 48 ) [49]. A multicenter study in Japan revealed that the addition of 48-week Peg-IFN $\alpha$ treatment in HBeAgpositive and -negative patients who received TDF maintenance therapy for $\geq 12$ weeks showed a sharp decline in HBsAg by $0.2 \log _{10} \mathrm{IU} / \mathrm{mL} /$ year, more often than with TDF monotherapy ( $41 \%$ vs. $2 \%, p<0.001)$. However, none of these patients displayed HBsAg seroclearance [50]. A single-arm, observational study (HERMES) in Italy that assessed HBeAg-negative patients with genotype D HBV infection revealed that the addition of 48-week Peg-IFN $\alpha$ to ongoing NA regimens (mostly with ETV or TDF) for $\geq 1$ year decreased HBsAg by $\geq 0.5-\log _{10} \mathrm{IU} / \mathrm{mL}$ and $\geq 1-\log _{10} \mathrm{IU} / \mathrm{mL}$ in $44.2 \%$ and $14.0 \%$ of patients at week 48 and $30.9 \%$ and $10.9 \%$ of patients at week 96 , respectively; only one patient had HBsAg loss [51].

In summary, most studies demonstrated that the addition of a finite course of PegIFN $\alpha$ to ETV or TDF treatment resulted in further decline in HBsAg levels but maintained the low rate of HBsAg seroclearance in the short term. Fundamentally, NA treatment is continued in add-on combination therapy; thus, it is safer than sequential combination therapy that aims toward the termination of NA therapy and a drug-free state. However, it is still unknown whether the decline in HBsAg will lead to HBsAg loss. Therefore, long-term follow-up studies are needed.

\section{Conclusions}

It is still unclear whether combination therapy is superior than monotherapy for treating chronic HBV infection. Some studies concerning simultaneous, sequential, or add-on combination therapy using ETV or TDF with Peg-IFN $\alpha$ showed promising results. Notably, sequential combination therapy could be a safe method for terminating long-term NA therapy, although the appropriate patient candidates for the therapy remain to be elucidated. However, there is no robust evidence that combination therapy is superior to monotherapy. Although the decline in HBsAg levels was greater with combination therapy, the rates of HBsAg loss did not significantly increase in most studies. As the addition of Peg-IFN $\alpha$ increases cost and side effects, this strategy should be carefully assessed for individual patients, weighing all potential advantages and disadvantages. Currently, all major practice guidelines do not recommend combination therapy. Therefore, large studies are needed to assess the safety and efficacy of combination therapy to increase the rates of HBsAg seroclearance over the long term [52]. In addition, some novel direct-acting antivirals, including nucleic acid polymers and capsid assembly modulators, are under investigation in clinical trials in combination with NA and/or Peg-IFN $\alpha[53,54]$.

Author Contributions: K.Y. and M.E. contributed to the study conception and design. Search and selection of abstracts, review of the full length articles, and writing the final version of the manuscript were performed by all authors. All authors have read and agreed to the published version of the manuscript.

Funding: This work was supported by Health and Labour Sciences Research Grants (Policy Research for Hepatitis Measures) from the Ministry of Health, Labour and Welfare of Japan (20HC1001). 
Conflicts of Interest: Shuhei Nishiguchi has received research grants from Gilead Sciences. Norifumi Kawada has received grants from Bristol-Myers K.K., GlaxoSmithKline, Gilead Sciences, and Chugai Pharmaceutical Co., Ltd.

$\begin{array}{ll}\text { Abbreviations } \\ \text { ALT } & \text { Alanine aminotransferase } \\ \text { ccCDNA } & \text { Covalently closed circular DNA } \\ \text { ETV } & \text { Entecavir } \\ \text { HBeAg } & \text { Hepatitis B e-antigen } \\ \text { HBsAg } & \text { Hepatitis B surface antigen } \\ \text { HBV } & \text { Hepatitis B virus } \\ \text { HCC } & \text { Hepatocellular carcinoma } \\ \text { NA } & \text { Nucleoside/nucleotide analogue } \\ \text { peg-IFN } \alpha & \text { Pegylated interferon- } \alpha \\ \text { TAF } & \text { Tenofovir alafenamide } \\ \text { TDF } & \text { Tenofovir disoproxil fumarate }\end{array}$

\section{References}

1. European Association for the Study of the Liver. EASL 2017 Clinical Practice Guidelines on the management of hepatitis B virus infection. J. Hepatol. 2017, 67, 370-398. [CrossRef] [PubMed]

2. Terrault, N.A.; Lok, A.; McMahon, B.J.; Chang, K.M.; Hwang, J.P.; Jonas, M.M.; Brown, R.S., Jr.; Bzowej, N.H.; Wong, J.B. Update on prevention, diagnosis, and treatment of chronic hepatitis B: AASLD 2018 hepatitis B guidance. Hepatology 2018, 67, 1560-1599. [CrossRef] [PubMed]

3. Sarin, S.K.; Kumar, M.; Lau, G.K.; Abbas, Z.; Chan, H.L.; Chen, C.J.; Chen, D.S.; Chen, H.L.; Chen, P.J.; Chien, R.N.; et al. Asian-Pacific clinical practice guidelines on the management of hepatitis B: A 2015 update. Hepatol. Int. 2016, 10, 1-98. [CrossRef] [PubMed]

4. Drafting Committee for Hepatitis Management Guidelines, the Japan Society of Hepatology. Japan Society of Hepatology Guidelines for the Management of Hepatitis B Virus Infection: 2019 update. Hepatol. Res. 2020, 50, 892-923. [CrossRef] [PubMed]

5. Mouzannar, K.; Liang, T.J. Hepatitis B virus-Recent therapeutic advances and challenges to cure. J. Hepatol. 2020, 73, 694-695. [CrossRef] [PubMed]

6. Thimme, R.; Dandri, M. Dissecting the divergent effects of interferon-alpha on immune cells: Time to rethink combination therapy in chronic hepatitis B. J. Hepatol. 2013, 58, 205-209. [CrossRef]

7. Murata, K.; Asano, M.; Matsumoto, A.; Sugiyama, M.; Nishida, N.; Tanaka, E.; Inoue, T.; Sakamoto, M.; Enomoto, N.; Shirasaki, T.; et al. Induction of IFN- $\lambda 3$ as an additional effect of nucleotide, not nucleoside, analogues: A new potential target for HBV infection. Gut 2018, 67, 362-371. [CrossRef]

8. Koike, K.; Suyama, K.; Ito, H.; Itoh, H.; Sugiura, W. Randomized prospective study showing the non-inferiority of tenofovir to entecavir in treatment-naïve chronic hepatitis B patients. Hepatol. Res. 2018, 48, 59-68. [CrossRef]

9. Choi, J.; Kim, H.J.; Lee, J.; Cho, S.; Ko, M.J.; Lim, Y.S. Risk of Hepatocellular Carcinoma in Patients Treated with Entecavir vs Tenofovir for Chronic Hepatitis B: A Korean Nationwide Cohort Study. JAMA Oncol. 2019, 5, 30-36. [CrossRef]

10. Tseng, C.H.; Hsu, Y.C.; Chen, T.H.; Ji, F.; Chen, I.S.; Tsai, Y.N.; Hai, H.; Thuy, L.; Hosaka, T.; Sezaki, H.; et al. Hepatocellular carcinoma incidence with tenofovir versus entecavir in chronic hepatitis B: A systematic review and meta-analysis. Lancet Gastroenterol. Hepatol. 2020, 5, 1039-1052. [CrossRef]

11. Boni, C.; Laccabue, D.; Lampertico, P.; Giuberti, T.; Viganò, M.; Schivazappa, S.; Alfieri, A.; Pesci, M.; Gaeta, G.B.; Brancaccio, G.; et al. Restored function of HBV-specific T cells after long-term effective therapy with nucleos(t)ide analogues. Gastroenterology 2012, 143, 963-973. [CrossRef] [PubMed]

12. Ye, B.; Liu, X.; Li, X.; Kong, H.; Tian, L.; Chen, Y. T-cell exhaustion in chronic hepatitis B infection: Current knowledge and clinical significance. Cell Death Dis. 2015, 6, e1694. [CrossRef] [PubMed]

13. Wieland, S.F.; Eustaquio, A.; Whitten-Bauer, C.; Boyd, B.; Chisari, F.V. Interferon prevents formation of replication-competent hepatitis B virus RNA-containing nucleocapsids. Proc. Natl. Acad. Sci. USA 2005, 102, 9913-9917. [CrossRef] [PubMed]

14. Belloni, L.; Allweiss, L.; Guerrieri, F.; Pediconi, N.; Volz, T.; Pollicino, T.; Petersen, J.; Raimondo, G.; Dandri, M.; Levrero, M. IFN- $\alpha$ inhibits HBV transcription and replication in cell culture and in humanized mice by targeting the epigenetic regulation of the nuclear cccDNA minichromosome. J. Clin. Investig. 2012, 122, 529-537. [CrossRef] [PubMed]

15. Micco, L.; Peppa, D.; Loggi, E.; Schurich, A.; Jefferson, L.; Cursaro, C.; Panno, A.M.; Bernardi, M.; Brander, C.; Bihl, F.; et al. Differential boosting of innate and adaptive antiviral responses during pegylated-interferon-alpha therapy of chronic hepatitis $B$. J. Hepatol. 2013, 58, 225-233. [CrossRef] [PubMed] 
16. Marcellin, P.; Lau, G.K.; Bonino, F.; Farci, P.; Hadziyannis, S.; Jin, R.; Lu, Z.M.; Piratvisuth, T.; Germanidis, G.; Yurdaydin, C.; et al. Peginterferon Alfa-2a HBeAg-Negative Chronic Hepatitis B Study Group. Peginterferon alfa-2a alone, lamivudine alone, and the two in combination in patients with HBeAg-negative chronic hepatitis B. N. Engl. J. Med. 2004, 351, 1206-1217. [CrossRef] [PubMed]

17. Lau, G.K.; Piratvisuth, T.; Luo, K.X.; Marcellin, P.; Thongsawat, S.; Cooksley, G.; Gane, E.; Fried, M.W.; Chow, W.C.; Paik, S.W.; et al. Peginterferon Alfa-2a HBeAg-Positive Chronic Hepatitis B Study Group. Peginterferon Alfa-2a, lamivudine, and the combination for HBeAg-positive chronic hepatitis B. N. Engl. J. Med. 2005, 352, 2682-2695. [CrossRef]

18. Enomoto, M.; Tamori, A.; Kohmoto, M.T.; Hayashi, T.; Jomura, H.; Habu, D.; Sakaguchi, H.; Takeda, T.; Kawada, N.; Seki, S.; et al. Lamivudine and IFN-beta sequential therapy in HBe antigen-positive patients with chronic hepatitis $\mathrm{B}$ virus genotype $\mathrm{C}$ infection. J. Interferon Cytokine Res. 2007, 27, 201-207. [CrossRef]

19. Enomoto, M.; Nishiguchi, S.; Tamori, A.; Kobayashi, S.; Sakaguchi, H.; Shiomi, S.; Kim, S.R.; Enomoto, H.; Saito, M.; Imanishi, H.; et al. Entecavir and interferon- $\alpha$ sequential therapy in Japanese patients with hepatitis B e antigen-positive chronic hepatitis B. J. Gastroenterol. 2013, 48, 397-404. [CrossRef]

20. Enomoto, M.; Tamori, A.; Nishiguchi, S.; Kawada, N. Combination therapy with a nucleos(t)ide analogue and interferon for chronic hepatitis B: Simultaneous or sequential. J. Gastroenterol. 2013, 48, 999-1005. [CrossRef]

21. Chang, T.T.; Gish, R.G.; de Man, R.; Gadano, A.; Sollano, J.; Chao, Y.C.; Lok, A.S.; Han, K.H.; Goodman, Z.; Zhu, J.; et al. A comparison of entecavir and lamivudine for HBeAg-positive chronic hepatitis B. N. Engl. J. Med. 2006, 354, 1001-1010. [CrossRef] [PubMed]

22. Lai, C.L.; Shouval, D.; Lok, A.S.; Chang, T.T.; Cheinquer, H.; Goodman, Z.; DeHertogh, D.; Wilber, R.; Zink, R.C.; Cross, A.; et al. Entecavir versus lamivudine for patients with HBeAg-negative chronic hepatitis B. N. Engl. J. Med. 2006, 354, 1011-1020. [CrossRef] [PubMed]

23. Marcellin, P.; Heathcote, E.J.; Buti, M.; Gane, E.; de Man, R.A.; Krastev, Z.; Germanidis, G.; Lee, S.S.; Flisiak, R.; Kaita, K.; et al. Tenofovir disoproxil fumarate versus adefovir dipivoxil for chronic hepatitis B. N. Engl. J. Med. 2008, 359, 2442-2455. [CrossRef]

24. Chan, H.L.; Fung, S.; Seto, W.K.; Chuang, W.L.; Chen, C.Y.; Kim, H.J.; Hui, A.J.; Janssen, H.L.; Chowdhury, A.; Tsang, T.Y.; et al. Tenofovir alafenamide versus tenofovir disoproxil fumarate for the treatment of HBeAg-positive chronic hepatitis B virus infection: A randomised, double-blind, phase 3, non-inferiority trial. Lancet Gastroenterol. Hepatol. 2016, 1, 185-195. [CrossRef]

25. Buti, M.; Gane, E.; Seto, W.K.; Chan, H.L.; Chuang, W.L.; Stepanova, T.; Hui, A.J.; Lim, Y.S.; Mehta, R.; Janssen, H.L. Tenofovir alafenamide versus tenofovir disoproxil fumarate for the treatment of patients with HBeAg-negative chronic hepatitis B virus infection: A randomised, double-blind, phase 3, non-inferiority trial. Lancet Gastroenterol. Hepatol. 2016, 1, 196-206. [CrossRef]

26. Tangkijvanich, P.; Chittmittraprap, S.; Poovorawan, K.; Limothai, U.; Khlaiphuengsin, A.; Chuaypen, N.; Wisedopas, N.; Poovorawan, Y. A randomized clinical trial of peginterferon alpha-2b with or without entecavir in patients with HBeAg-negative chronic hepatitis B: Role of host and viral factors associated with treatment response. J. Viral Hepat. 2016, 23, 427-438. [CrossRef]

27. Hagiwara, S.; Kudo, M.; Osaki, Y.; Matsuo, H.; Inuzuka, T.; Matsumoto, A.; Tanaka, E.; Sakurai, T.; Ueshima, K.; Inoue, T. Impact of peginterferon alpha- $2 \mathrm{~b}$ and entecavir hydrate combination therapy on persistent viral suppression in patients with chronic hepatitis B. J. Med. Virol. 2013, 85, 987-995. [CrossRef]

28. Hagiwara, S.; Nishida, N.; Watanabe, T.; Ida, H.; Sakurai, T.; Ueshima, K.; Takita, M.; Komeda, Y.; Nishijima, N.; Osaki, Y.; et al. Sustained antiviral effects and clearance of hepatitis surface antigen after combination therapy with entecavir and pegylated interferon in chronic hepatitis B. Antivir. Ther. 2018, 23, 513-521. [CrossRef]

29. Marcellin, P.; Ahn, S.H.; Ma, X.; Caruntu, F.A.; Tak, W.Y.; Elkashab, M.; Chuang, W.L.; Lim, S.G.; Tabak, F.; Mehta, R.; et al. Combination of Tenofovir Disoproxil Fumarate and Peginterferon $\alpha$-2a Increases Loss of Hepatitis B Surface Antigen in Patients with Chronic Hepatitis B. Gastroenterology 2016, 150, 134-144. [CrossRef]

30. Ahn, S.H.; Marcellin, P.; Ma, X.; Caruntu, F.A.; Tak, W.Y.; Elkhashab, M.; Chuang, W.L.; Tabak, F.; Mehta, R.; Petersen, J.; et al. Hepatitis B Surface Antigen Loss with Tenofovir Disoproxil Fumarate Plus Peginterferon Alfa-2a: Week 120 Analysis. Dig. Dis. Sci. 2018, 63, 3487-3497. [CrossRef]

31. Zheng, C.; Yan, H.; Zeng, J.; Cai, S.; Wu, X. Comparison of pegylated interferon monotherapy and de novo pegylated interferon plus tenofovir combination therapy in patients with chronic hepatitis B. Infect. Drug Resist. 2019, 12, 845-854. [CrossRef] [PubMed]

32. de Niet, A.; Jansen, L.; Stelma, F.; Willemse, S.B.; Kuiken, S.D.; Weijer, S.; van Nieuwkerk, C.; Zaaijer, H.L.; Molenkamp, R.; Takkenberg, R.B. Peg-interferon plus nucleotide analogue treatment versus no treatment in patients with chronic hepatitis B with a low viral load: A randomised controlled, open-label trial. Lancet Gastroenterol. Hepatol. 2017, 2, 576-584. [CrossRef]

33. Ning, Q.; Han, M.; Sun, Y.; Jiang, J.; Tan, D.; Hou, J.; Tang, H.; Sheng, J.; Zhao, M. Switching from entecavir to PegIFN alfa-2a in patients with HBeAg-positive chronic hepatitis B: A randomised open-label trial (OSST trial). J. Hepatol. 2014, 61, 777-784. [CrossRef] [PubMed]

34. Han, M.; Jiang, J.; Hou, J.; Tan, D.; Sun, Y.; Zhao, M.; Ning, Q. Sustained immune control in HBeAg-positive patients who switched from entecavir therapy to pegylated interferon- $\alpha 2 a$ : 1 year follow-up of the OSST study. Antivir. Ther. 2016, 21, 337-344. [CrossRef]

35. Zhou, Y.; Yan, R.; Ru, G.Q.; Yu, L.L.; Yao, J.; Wang, H. Pegylated-interferon consolidation treatment versus nucleos(t)ide analogue consolidation treatment in non-cirrhotic hepatitis B patients with hepatitis B e antigen seroconversion: An open-label pilot trial. Hepatol. Int. 2019, 13, 422-430. [CrossRef] 
36. Huang, J.; Zhang, K.; Chen, W.; Liao, J.; Luo, X.; Chen, R. Switching to PegIFN $\alpha-2 b$ leads to HBsAg loss in patients with low HBsAg levels and HBV DNA suppressed by NAs. Sci. Rep. 2017, 7, 13383. [CrossRef]

37. Hu, P.; Shang, J.; Zhang, W.; Gong, G.; Li, Y.; Chen, X.; Jiang, J.; Xie, Q.; Dou, X.; Sun, Y.; et al. HBsAg Loss with Peg-interferon Alfa-2a in Hepatitis B Patients with Partial Response to Nucleos(t)ide Analog: New Switch Study. J. Clin. Transl. Hepatol. 2018, 6, 25-34. [CrossRef]

38. Xie, Q.; Zhou, H.; Bai, X.; Wu, S.; Chen, J.J.; Sheng, J.; Xie, Y.; Chen, C.; Chan, H.L.; Zhao, M. A randomized, open-label clinical

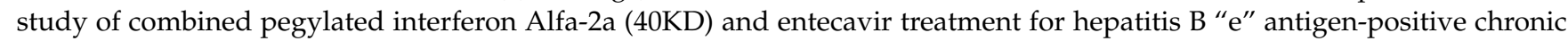
hepatitis B. Clin. Infect. Dis. 2014, 59, 1714-1723. [CrossRef]

39. Tamaki, N.; Kurosaki, M.; Kusakabe, A.; Orito, E.; Joko, K.; Kojima, Y.; Kimura, H.; Uchida, Y.; Hasebe, C.; Asahina, Y.; et al. Hepatitis B surface antigen reduction by switching from long-term nucleoside/nucleotide analogue administration to pegylated interferon. J. Viral Hepat. 2017, 24, 672-678. [CrossRef]

40. Matsumoto, A.; Nishiguchi, S.; Enomoto, H.; Kang, J.H.; Tanaka, Y.; Shinkai, N.; Kurosaki, M.; Enomoto, M.; Kanda, T.; Yokosuka, O.; et al. Combinational use of hepatitis B viral antigens predicts responses to nucleos(t)ide analogue/peg-interferon sequential therapy. J. Gastroenterol. 2018, 53, 247-257. [CrossRef]

41. Kimura, T.; Rokuhara, A.; Sakamoto, Y.; Yagi, S.; Tanaka, E.; Kiyosawa, K.; Maki, N. Sensitive enzyme immunoassay for hepatitis B virus core-related antigens and their correlation to virus load. J. Clin. Microbiol. 2002, 40, 439-445. [CrossRef] [PubMed]

42. Yoshida, K.; Desbiolles, A.; Feldman, S.F.; Ahn, S.H.; Alidjinou, E.K.; Atsukawa, M.; Bocket, L.; Brunetto, M.R.; Buti, M.; Carey, I.; et al. Assay for Hepatitis B Core-related Antigen Identify Patients with High Viral Load: Systematic Review and Meta-analysis of Individual Participant Data. Clin. Gastroenterol. Hepatol. 2020, 46-60. [CrossRef]

43. Enomoto, M.; Nishiguchi, S.; Tamori, A.; Kozuka, R.; Fujii, H.; Uchida-Kobayashi, S.; Fukunishi, S.; Tsuda, Y.; Higuchi, K.; Saito, M.; et al. Sequential therapy involving an early switch from entecavir to pegylated interferon- $\alpha$ in Japanese patients with chronic hepatitis B. Hepatol. Res. 2018, 48, 459-468. [CrossRef] [PubMed]

44. Brouwer, W.P.; Xie, Q.; Sonneveld, M.J.; Zhang, N.; Zhang, Q.; Tabak, F.; Streinu-Cercel, A.; Wang, J.Y.; Idilman, R.; Reesink, H.W.; et al. Adding pegylated interferon to entecavir for hepatitis B e antigen-positive chronic hepatitis B: A multicenter randomized trial (ARES study). Hepatology 2015, 61, 1512-1522. [CrossRef]

45. Van Campenhout, M.; Brouwer, W.P.; Xie, Q.; Guo, S.; Chi, H.; Qi, X.; Tabak, F.; Streinu-Cercel, A.; Wang, J.Y.; Zhang, N.P.; et al. Long-term follow-up of patients treated with entecavir and peginterferon add-on therapy for HBeAg-positive chronic hepatitis $B$ infection: ARES long-term follow-up. J. Viral. Hepat. 2019, 26, 109-117. [CrossRef]

46. Chi, H.; Hansen, B.E.; Guo, S.; Zhang, N.P.; Qi, X.; Chen, L.; Guo, Q.; Arends, P.; Wang, J.Y.; Verhey, E.; et al. Pegylated Interferon Alfa-2b Add-on Treatment in Hepatitis B Virus Envelope Antigen-Positive Chronic Hepatitis B Patients Treated with Nucleos(t)ide Analogue: A Randomized, Controlled Trial (PEGON). J. Infect. Dis. 2017, 215, 1085-1093. [CrossRef]

47. Liem, K.S.; van Campenhout, M.; Xie, Q.; Brouwer, W.P.; Chi, H.; Qi, X.; Chen, L.; Tabak, F.; Hansen, B.E.; Janssen, H. Low hepatitis B surface antigen and HBV DNA levels predict response to the addition of pegylated interferon to entecavir in hepatitis B e antigen positive chronic hepatitis B. Aliment. Pharmacol. Ther. 2019, 49, 448-456. [CrossRef]

48. Bourlière, M.; Rabiega, P.; Ganne-Carrie, N.; Serfaty, L.; Marcellin, P.; Barthe, Y.; Thabut, D.; Guyader, D.; Hezode, C.; Picon, M.; et al. Effect on HBs antigen clearance of addition of pegylated interferon alfa-2a to nucleos(t)ide analogue therapy versus nucleos(t)ide analogue therapy alone in patients with HBe antigen-negative chronic hepatitis B and sustained undetectable plasma hepatitis B virus DNA: A randomised, controlled, open-label trial. Lancet Gastroenterol. Hepatol. $2017,2,177-188$.

49. Li, G.J.; Yu, Y.Q.; Chen, S.L.; Fan, P.; Shao, L.Y.; Chen, J.Z.; Li, C.S.; Yi, B.; Chen, W.C.; Xie, S.Y.; et al. Sequential combination therapy with pegylated interferon leads to loss of hepatitis B surface antigen and hepatitis B e antigen (HBeAg) seroconversion in HBeAg-positive chronic hepatitis B patients receiving long-term entecavir treatment. Antimicrob. Agents Chemother. 2015, 59, 4121-4128. [CrossRef]

50. Matsumoto, A.; Nishiguchi, S.; Enomoto, H.; Tanaka, Y.; Shinkai, N.; Okuse, C.; Kang, J.H.; Matsui, T.; Miyase, S.; Yatsuhashi, H.; et al. Pilot study of tenofovir disoproxil fumarate and pegylated interferon-alpha 2a add-on therapy in Japanese patients with chronic hepatitis B. J. Gastroenterol. 2020, 55, 977-989. [CrossRef]

51. Lampertico, P.; Brunetto, M.R.; Craxì, A.; Gaeta, G.B.; Rizzetto, M.; Rozzi, A.; Colombo, M.; HERMES Study Group. Add-on peginterferon alfa-2a to nucleos(t)ide analogue therapy for Caucasian patients with hepatitis B ' $\mathrm{e}^{\prime}$ antigen-negative chronic hepatitis B genotype D. J. Viral. Hepat. 2019, 26, 118-125. [CrossRef]

52. Enomoto, M.; Nishiguchi, S.; Tamori, A.; Kozuka, R.; Hayashi, T.; Kohmoto, M.T.; Jomura, H.; Morikawa, H.; Murakami, Y.; Shiomi, S.; et al. Long-Term Outcome of Sequential Therapy with Lamivudine Followed by Interferon- $\beta$ in Nucleoside-Naive, Hepatitis B e-Antigen-Positive Patients with Chronic Hepatitis B Virus Genotype C Infection. J. Interferon Cytokine Res. 2015, 35, 613-620. [CrossRef] [PubMed]

53. Bazinet, M.; Pântea, V.; Placinta, G.; Moscalu, I.; Cebotarescu, V.; Cojuhari, L.; Jimbei, P.; Iarovoi, L.; Smesnoi, V.; Musteata, T.; et al. Safety and Efficacy of 48 Weeks REP 2139 or REP 2165, Tenofovir Disoproxil, and Pegylated Interferon Alfa-2a in Patients With Chronic HBV Infection Naïve to Nucleos(t)ide Therapy. Gastroenterology 2020, 158, 2180-2194. [CrossRef] [PubMed]

54. Janssen, H.L.A.; Hou, J.; Asselah, T.; Chan, H.L.Y.; Zoulim, F.; Tanaka, Y.; Janczewska, E.; Nahass, R.; Bourgeois, S.; Buti, M.; et al. Efficacy and Safety Results of the Phase 2 JNJ-56136379 JADE Study in Patients with Chronic Hepatitis B: Interim Week 24 Data. J. Hepatol. 2020, 73, S129-S130. [CrossRef] 